
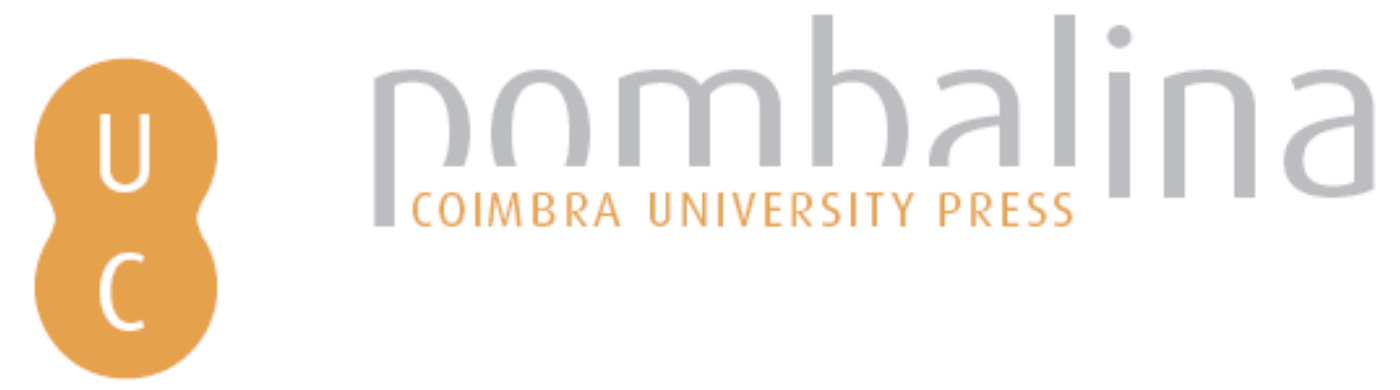

\title{
O clássico em Vitorino Nemésio: uma leitura de mau tempo no canal segundo as características da tragédia Grega
}

Autor(es): $\quad$ Dias, Paula Barata

Publicado por: Imprensa da Universidade de Coimbra

URL

persistente: URI:http://hdl.handle.net/10316.2/37045

DOI: $\quad$ DOI:http://dx.doi.org/10.14195/978-989-26-1043-6_10

Accessed : $\quad$ 26-Apr-2023 11:29:09

A navegação consulta e descarregamento dos títulos inseridos nas Bibliotecas Digitais UC Digitalis, UC Pombalina e UC Impactum, pressupõem a aceitação plena e sem reservas dos Termos e Condições de Uso destas Bibliotecas Digitais, disponíveis em https://digitalis.uc.pt/pt-pt/termos.

Conforme exposto nos referidos Termos e Condições de Uso, o descarregamento de títulos de acesso restrito requer uma licença válida de autorização devendo o utilizador aceder ao(s) documento(s) a partir de um endereço de IP da instituição detentora da supramencionada licença.

Ao utilizador é apenas permitido o descarregamento para uso pessoal, pelo que o emprego do(s) título(s) descarregado(s) para outro fim, designadamente comercial, carece de autorização do respetivo autor ou editor da obra.

Na medida em que todas as obras da UC Digitalis se encontram protegidas pelo Código do Direito de Autor e Direitos Conexos e demais legislação aplicável, toda a cópia, parcial ou total, deste documento, nos casos em que é legalmente admitida, deverá conter ou fazer-se acompanhar por este aviso.

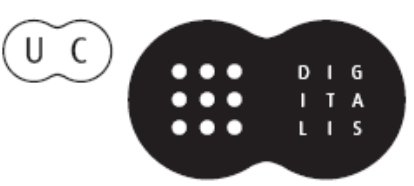


politica no Brasil do sécu

Categorias aristotélicas por Silvestre Pinheiro Ferreira - Musas errantes: tesouros da Antiguidade Clássica no labirinto da Biblioteca Nacional Brasileira - Eudoro de Sousa e a Mitologia • Câmara Cascudo em defesa de Epicuro - Medéia carioca - Ecos de Platão em Vergílio Ferreira - Imaginário clássico na poesia de António Arnaut - Motivos clássicos na poesia novilatina em Portugal: Manuel da Costa - Uma Ifigénia portuguesa: "Noite escura" de João Canijo • Uma leitura de Mau Tempo no Canal de Vitorino Nemésio $\bullet A$ phýsis grega e o Brasil: as viagens de Von Martius $\bullet$ Fantasia para dois coronéis e uma piscina. Ecos clássicos num contexto do séc. XX

\section{A RECEPÇÃO DOS CLÁSSICOS EM PORTUGAL E NO BRASIL}

Maria de Fátima Silva Maria das Graças de Moraes Augusto COORDENAÇÃo 


\section{SÉRIE MITO E (RE)ESCRITA}

ISSN: $2182-8814$

\section{PERIODICIDADE: Anual}

Apresentação: Poetas, pintores, escultores, na Antiguidade, familiarizados com mitos antigos de deuses e de homens, que cristalizavam experiências, interrogaçóes, respostas quanto à existência do homem no tempo e no mundo, em mitos se inspiraram, em contínua criação-recriaçẩo, para neles verterem a sua própria experiência temporal, com todos os desassossegos e inquietaçóes, com todo o espanto, horror ou encantamento pela excecionalidade da ação humana, que rasga ou ilumina fronteiras de finitude. Esses percursos da criação merecem, hoje, a atenção e análise dos Estudos Literários e, como não podia deixar de ser, dos Estudos Clássicos, muito peculiarmente. Importa, pois, proceder à publicação sistemática de estudos deste cariz, que se destaquem pela qualidade científica e pela originalidade, sendo dedicados, sobretudo, a autores de língua portuguesa. Assim se dá corpo à linha editorial MITO E (RE)ESCRITA.

Este livro, realizado no âmbito do Convénio de Cooperação Académica entre o CECH - Centro de Estudos Clássicos e Humanísticos da UC - e o PRAGMA - Programa de Estudos de Filosofia Antiga da UFRJ -, reúne um conjunto de estudos sobre a recepçáo de temas e modelos greco-latinos na literatura e cultura de Portugal e Brasil.

A sua originalidade resulta da participação de diferentes culturas e das especialidades académicas diversas dos investigadores que nele participam, provenientes da Literatura, da Filosofia e da História Antiga. O lapso de tempo abrangido, que vai do séc. XVI ao XX, permite uma visáo de conjunto da evoluçáo operada no perfil cultural de ambos os países e na definição de um trajeto em boa parte comum. 


\section{O Clássico em Vitorino Nemésio - Uma Leitura de Mau Tempo no Canal segundo as características da Tragédia Grega}

(A Lecture of Vitorino Nemésio's Mau tempo no canal, in accordance with tragic structures)

Paula Barata Dias

Centro de Estudos Clássicos e Humanísticos da Universidade de Coimbra (pabadias@hotmail.com) 
Página deixada propositadamente em branco 
Resumo - Vitorino Nemésio filia-se num sentido de clássico universal, não sujeito às amarras da intertextualidade evidente ou à evocaçáo explícita dos mitos da civilizaçáo greco-romana, ou mesmo a um modelo formal recebido de uma disciplina literária traçada na Antiguidade. Exprimindo-se com ironia, o autor decompóe o termo desde a base, rejeitando o conceito de clássico enquanto estilo artístico que se opõe a outro estilo, ou que é reivindicado enquanto fator de nobilitaçáo para uma obra de que se pretende exaltar o valor. Fixa-se no valor da "permanência da sua significação" no clássico intemporal que decorre da qualidade da obra.

Palavras chave - literatura portuguesa do séc. XX, Açores.

Abstract - Vitorino Nemésio adopts a sense of universal classicism, not creating a true dialogue or a explicit evocation of Greco-Roman myths or models. He expresses himself with irony, rejecting the sense of classicism as an artistic style or as an argument of dignity for some new creation. He stresses his permanence of sense coming from its perfection.

KEYWORDs - Portuguese literature of the twenties, Azores.

Vitorino Nemésio (1901-1978), nascido em 1901 na Praia da Vitória, ilha Terceira dos Açores, é um dos grandes autores literários do séc. XX português, dono de uma obra ímpar, arredia a uma classificação fácil de acordo com as correntes e as escolas literárias dominantes do séc. XX, complexa, na pluralidade dos géneros percorridos, capaz de se reinventar e de surpreender o leitor pelas ruturas assumidas ao longo de uma longeva biografia literária. Nemésio atravessou as geraçóes modernistas, conheceu o psicologismo da Presença e da geração presencista, testemunhou, como criador literário, os influxos tímidos do nouveau roman em Portugal, e caminhou em paralelo com a mais numerosa geraçáo de prosadores do Neo-realismo português. Contudo, de nenhuma destas correntes literárias dos primeiros dois terços do séc. XX português foi seguidor. Vitorino Nemésio é um caso único no panorama literário nacional, pela dificuldade da sua inserção numa corrente estética e literária, pela extensa e complexa obra, em todos os géneros, mas também pela coerência interna da mesma: estamos na presença de um "autor constelação", como o foram Fernando Pessoa, ou Miguel Torga, pois a análise da sua obra resulta não tanto do contexto da sua produção, mas muito mais do posicionamento de cada criação em relação à outra, da continuidade e da evolução entre elas, em suma, da sua leitura e interpretação dentro do universo criativo Nemesiano.

Participante da vida literária e intelectual desde os anos do final da República (1920-26), formou-se em Românicas na Universidade de Lisboa, de que foi professor catedrático até 9 de dezembro de 1971, altura 
em que se jubilou, a dez dias de completar setenta anos. A morte colheu-o aos 78 anos, ainda a ditar versos aos seus filhos, que os iam apontando. O seu desalinhamento em relação às correntes literárias dominantes, associado a uma originalidade intrínseca, feita de escassas ruturas formais quanto à estrutura dos géneros que cultivou, teve certamente consequências na receção da sua obra, que não recebe, quanto a nós, a atenção cuja grandeza suscitaria.

Mau Tempo no Canal é hoje considerado um dos melhores, senão a obra-prima do romance português do séc. $\mathrm{XX}^{1}$. No entanto, o seu reconhecimento foi tardio. Publicado em 1944, o romance teve fraca repercussão entre o público e a crítica da altura. Nos anos setenta, a $2^{a}$ edição da obra pela editora Bertrand contribuiu para a renovação do interesse por esta obra de toada única, desvendando o seu valor e a sua qualidade no panorama das letras nacionais. Maria Lúcia Lepecki, Óscar Lopes, António Machado Pires, José Martins Garcia, e David Mourão Ferreira puderam, entáo alertar para a singularidade do romance Nemesiano.

Como explicar este obnubilar durante quase meio século? Nemésio é um autor constelação mas em que a poesia esmaga e absorve quem por aí inicia o contacto com o autor. Assim, em 1998, vinte anos após a sua morte, realizou-se o Colóquio Internacional de Estudos Nemesianos em Ponta Delgada, sob o acolhimento da Universidade dos Açores e coordenação de um dos seus discípulos e assistentes na Universidade de Lisboa, António Machado Pires, então já professor catedrático da Universidade dos Açores. Oitenta comunicaçôes de estudiosos da sua obra, e contudo, sobre Mau Tempo no Canal apenas oito conferências. Foram entretanto publicadas em 2007 as actas do II congresso dedicado a Nemésio, ocorrido em Salvador da Baía em $2000^{2}$, que não alterou a situação.

Acresce ainda o facto de Vitorino Nemésio, e com maior força de razão a sua obra-prima em romance, MTC, terem sido de algum modo capturados pelo apodo de "autor de forte pulsão regionalista" e de "romance das ilhas", dando corpo a uma classificação literária defendida

1 Vitorino Nemésio (2008) Mau Tempo no Canal, 1944 (1a ed), Relógio d’Água. Citamos esta edição e usamos, doravante, a abreviatura MTC para referirmos a obra no nosso texto.

2 Comemoraçôes 1988; Pires 1988; Hoisel, Ribeiro 2007. 
pela natureza, pela especificidade histórica, social, cultural e política do Arquipélago do Atlântico, que teria marcado as expressôes criativas, estéticas e literárias nascidas nas ilhas - Literatura Açoriana e Açorianidade, em particular o último termo, cujo conceito coube ao próprio Nemésio definir em mais do que uma ocasiāo ${ }^{3}$, e que singrou enquanto conceito operativo na interpretação da obra de Nemésio em estudos recentes ${ }^{4}$. Obra-prima da Literatura Açoriana, considerada sob esse escopo, a ela escaparia o carácter universal das grandes obras, condição que se pode estender a outros escritores portugueses ${ }^{5}$.

Estará MTC cativo da classificação "Literatura Açoriana", versão académica de um conceito interpretativo defensável enquanto modo de defender um particularismo temático e estético, e uma identidade própria para os autores açorianos que situam a sua criação literária no espaço físico ou na mundividência açoriana, captando as particularidades linguísticas e culturais de uma regiāo, muitas vezes a partir já de uma diáspora e de pulverização geográfica assumidas. Mas se esta construção se sobrepuser a uma leitura mais universal de uma obra literária, como entender a poesia de Antero de Quental, ou como enquadrar Raúl Brandão, escritor português nascido no Porto, mas autor de As Ilhas Desconhecidas, obra tão

3 Nemésio 1932: 59. "Como homens, estamos soldados historicamente ao povo de onde viemos e enraizados pelo habitat a uns montes de lava que soltam da própria entranha uma substância que nos penetra. A geografia, para nós, vale outro tanto como a história, e não é debalde que as nossas recordações escritas inserem uns cinquenta por cento de relatos de sismos e enchentes. Como as sereias temos uma dupla natureza: somos de carne e pedra. Os nossos ossos mergulham no mar."

4 Baptista 2012: 17-19. https://repositorioaberto.uab.pt/.

5 Desta limitação padeceram os maiores prosadores da língua portuguesa do séc. XX, como Ferreira de Castro, Aquilino Ribeiro e o próprio Miguel Torga, envolvidos pela cor local dos temas, estilo, vocabulário de um determinado tipo de Portugal que pareciam limitar a grandeza da criação literária a eles associada. São estes autores para quem o manejo da substância literária suprema, que é o homem, se faz cúmplice e dependente de uma terra e de um espaço concretos - o mundo rural e as referências históricas a um certo Portugal - que não são apenas circunstâncias, mas eles próprios condicionadores do desenho das personagens, do enredo, e mesmo da linguagem. 
responsável pela projeção do conceito de insularidade açoriana ainda hoje dominante?

Escutar as palavras que Nemésio proferiu enquanto crítico literário e enquanto poeta torna-se imperioso se quisermos atestar a sensibilidade, ou mesmo a consciência explícita de uma relaçáo, de afinidade ou de afastamento entre si próprio, com o conceito de Clássico.

Em 1938, entáo Diretor da Revista de Portugal, Nemésio publicou uma recensão crítica à obra de Francisco Luiz de Sousa. Neste texto emite o seu entendimento sobre o que tornaria uma obra clássica, situando o texto do recenseado quanto a este valor ${ }^{6}$. Nemésio filia-se a um sentido de clássico universal, não sujeito às amarras da intertextualidade evidente ou à evocação explícita dos mitos da civilizaçáo greco-romana, ou mesmo a um modelo formal recebido de uma disciplina literária traçada na Antiguidade.

6 1938: 99-101 (Cardoso 2005, dissertação de mestrado). Transcrevemos o excerto completo: “ ..."Chamarei clássico ao que se lê em classe? Não digo isto com ar de censura: estabeleço factos a caminho de uma variação sobre o meu conceito de clássico. $\mathrm{O}$ clássico está pois definido como o escritor que foi objeto de classificação. (...) Mas há outra maneira menos primária de tirar o conceito de clássico dos meios oficiais da coisa escrita. É abordar a questão pelo lado dos clássicos e românticos. E clássico e romântico seráo dois modos de morte mutuamente incompatíveis, como classificador de coisas rebeldes, a classe é um modo de vida honesto. Náo quero saber do aspeto formal do classicismo para coisa nenhuma. Todo o apuro verbal que não seja expressão necessária é uma questão de toilette. Por expressão entendo eu que procuro saber que sentido está nas palavras, a própria pressão do que o escritor tem de comunicar, a sua libertaçáo íntima. O estilo, pois, consistia num discurso sem difusão, numeroso, vigiado de vírgulas, denunciante de uma experiência literária rica, tenderá a ser considerado como típico estilo clássico. Foi este o ideal de estilo de todos os tempos. Quer dizer: sempre se ligou à ideia da literatura noções de clareza, precisão e elegância. Mas, por isso mesmo que era um ideal de toda a gente, o deste estilo clássico precisou de desfazer-se em cada personalidade verdadeiramente válida, para se refazer ou se reconstituir segundo as leis dela. (...) Há um classicismo que vem aderido às palavras e às leis por que se agrupam. Esse é o sinal da ordem, de pensamento mais vivo que o sentimento, este recalcado e quanto possível tornado inteligível, esfriado na compreensão, mandado apagar-se para que a evidência seja inteiramente vista. Mas é um classicismo de pouca monta em face do verdadeiro, de que ele é um instrumento, um mero modo. O verdadeiro classicismo é o conjunto de valores que levam o escritor a uma significaçáo permanente. O que dá classe a um escritor é a dificuldade com que se descobriu a sua veia íntima, uma espécie de corda que se retrai, que não vibra senão à tensão máxima e ao mais puro esforço de ajustamento. Mas a essência do clássico ainda é o humano, e para falar de humano são precisas mais páginas do que estas e um ponto de partida mais vivo que o bom Fr. Luís de Sousa. Para clássicos do Humano: Gil Vicente, Camóes, Garrett, Antero e - embora desumanizado pelo abuso do próprio classicismo - Fernando Pessoa". 
Exprimindo-se com ironia, o autor decompóe o termo desde a base, rejeitando o conceito de clássico enquanto estilo artístico que se opóe a outro estilo, ou que é reivindicado enquanto fator de nobilitaçáo para uma obra de que se pretende exaltar o valor. Nemésio fixa-se no valor da "permanência da sua significação" no clássico intemporal que decorre da qualidade da obra:

"O verdadeiro classicismo é o conjunto de valores que levam o escritor a uma significação permanente. O que dá classe a um escritor é a dificuldade com que se descobriu a sua veia íntima, uma espécie de corda que se retrai, que não vibra senão à tensão máxima e ao mais puro esforço de ajustamento."

O "Clássico" pode traduzir-se também na intelectualização do sentimento, que assume uma forma ordenada, clara, esteticamente harmónica, mas este clássico é apenas um instrumento, não é na forma, nem na adoção de um estilo literário que se gera uma obra clássica. Ao enfatizar a "permanência da significaçáo" o clássico de Nemésio é uma atribuição que só o destinatário, na receção, pode conceder.

Noutro apontamento crítico, observamos o distanciamento de Nemésio face a uma receção explícita do património mitológico grego e romano enquanto grande fábrica de histórias referenciais da história cultural ocidental, considerando-a um processo fatalmente mumificado7.

Em duas obras deixou o poeta Nemésio gravada a sua relação com o clássico. As duas composiçóes, separadas por décadas, apresentam grandes semelhanças. A torná-las fundamentais para o assunto que nos ocupa está o facto de as duas serem essencialmente autorretratos. Publicado em 1916, o jovem Nemésio exprime assim a sua "angústia da influência" ${ }^{8}$, depressa subvertendo o seu papel passivo de recetor, para se tornar ele próprio a luz que revitaliza o passado literário:

\footnotetext{
"beijei Homero, e Dante, e Buda, e Prometeu! eu moro no ideal. E Newton e Platáo
}

7 Cardoso 2005: 50 cita Vitorino Nemésio na sua recensão à obra As Mãos e os Frutos de Eugénio de Andrade, 1948: 199: “o mito já agoniza epicamente em Camões, como herdado de Píndaro, morre no Eros de Ronsard. Daí por diante o ocaso do mito é evidente. Com mais ou menos pelo, e sempre com menos sangue - o bode trágico, o anho e o bezerro idílicos vão-se mumificando".

8 Bloom ${ }^{2}$ 1991: 21. 
são os frutos do luar do meu amor loução

[...] eu sou uma centelha, um lampejo divino,

que iluminei o Grego e iluminei o Latino,

Iluminei a Safo, iluminei Virgil'o

E Fídias, e Verdi, e Sófocles e Murillo?.

Neste segundo poema, Nemésio assume-se como um misto de heranças antigas e étnicas, associando-lhes adjetivos que caraterizam genericamente os povos envolvidos. Há uma progressão cronológica ascendente, a que escapam, talvez, as referências à sua identidade enquanto "Cristão só nas conversas"; "Grego no corpo"; "Romano na ambição". Todas estas heranças identitárias, de espaços e de tempos antigos e contemporâneos, fazem do poeta "homem seja onde for". Este é um modo de assumir o denominador comum terenciano, que o libertará para qualquer aventura artística ou estética: é humano, e por isso nada lhe será alheio.
Cruel como os Assírios,
Lânguido como os Persas,
Entre estrelas e círios
Cristão só nas conversas.
Árabe no sossego,
Africano no ardor;
No corpo, Grego, Grego!
Homem seja onde for.
Romano na ambição,
Oriental no ardil,
Latino na paixão,
Europeu por subtil:
Homem sou, homem só
(Pascal: "nem anjo nem bruto")
Cristamente do pó
Me levanto impoluto. ${ }^{10}$

Fomos levados a refletir sobre a estrutura trágica de MTC pela consciência de que a leitura "regional" da obra, apresentada por Lepecki e

\footnotetext{
9 “O Génio", Nemésio 1916: 10.

10 "Retrato", Nemésio 1952: 87.
} 
pela generalidade dos estudiosos Nemesianos era redutora ${ }^{11}$, e que em MTC pulsava uma estrutura que, integrando o contexto e a realidade histórica, social e a mentalidade das ilhas, sofria uma pulsão mais antiga, e partilhada com a grande tradição literária ocidental filiada na herança da tragédia grega.

A leitura de Raymond Williams em Modern Tragedy permitiu-nos este exercício de procurar o trágico em MTC. Neste estudo teórico, reflete-se sobre o sentido comum que, nas sociedades contemporâneas e do discurso corrente, se atribui ao termo "tragédia" como modo particular de classificar um certo tipo de experiências "infortúnio"; "ocorrência infeliz"; e o sentido estrito, específico de um certo tipo de obra literária ${ }^{12}$. Analisa, de seguida, autores modernos, entre dramaturgos e romancistas (Stringberg, Tolstoy, Ionesco, Pasternak) segundo o tema "Literatura Trágica Moderna", mostrando que as características do trágico podem transcender a estrita classificação dos géneros literários como romance e prosa, por um lado; e poesia dramática ou tragédia, por outro. Ordena num capítulo inicial, antes de proceder à análise de vários autores, aquilo a que chama de "Tragic Ideas" 13 , as experiências humanas que, podendo ou náo ser presentes num enquadramento literário, são, em continuidade com a tradição clássica do género trágico, compreendidas na contemporaneidade como "trágicas". Resumimos as ideias principais: "ordem e acidente", acontecimentos arbitrários, dolorosos ou causadores

11 Esta "prisão insular" a envolver MTC foi apontada até pelos melhores conhecedores da obra, que aceitaram a sua condiçáo de romance de um espaço. Vide Lepecki 1971: 44-49. "É difícil encerrar MTC num rótulo. Nele se faz a apresentação, análise crítica de uma realidade social constituída no que se poderia classificar de macrocontexto insulano, e do outro, um micro contexto constituído pelas facçóes económicas e financeiras que se opõem, os Clarks e os Garcias. Para além disso, a própria paisagem dos lugares onde se passa a acção é essencial ao desenvolvimento do romance, visto como há uma especificidade insulana que, em certa medida, envolve e por vezes explica as personagens e os conflitos. Tornam-se essenciais as descriçóes da paisagem física - desde o clima até aos pormenores topográficos - e os estudos psicológicos. Ambos os elementos contribuem para tipificar o ilhéu. Núcleos básicos significativos: a oposição Clarks Dulmos e os Garcias; a miséria do povo face à opulência dos senhores das terras; a estrutura patriarcal da família; finalmente, a problemática pessoal de Margarida, em quem convergem todas as linhas de força do romance."

12 Williams 1966: 15: "Tragedy comes to us, as a word, from a long tradition of European civilization, and it's easy to see this tradition as a continuity in one important way: that so many of the later writers and thinkers have been conscious of the earlier, and have seen themselves as contributing to a common idea of form".

13 Williams 1966: 46-65. 
do sofrimento dos envolvidos, aquilo a que chamaríamos a força dos fados, ou do destino. A ordem, numa tragédia, é o resultado plausível de uma ação. Acidente é o resultado arbitrário. Qualquer deles tem idêntica capacidade de gerar sofrimento. "A destruiçāo do herói": a tragédia, afirma Williams, não é o que acontece ao herói, mas o que atravessa o herói, aquilo que transcende a sua vontade individual, ou capacidade de agir. "A ação irreparável": o caráter definitivo das escolhas feitas pelo homem, no sentido em que cada ação desencadeia o seu irrepetível curso de eventos, constituindo por si um limite ao controlo do indivíduo sobre a realidade. "A ênfase do Mal": afirma o autor que a tragédia nos mostra que o mal é inescapável e irreparável, sendo este um salutar aviso contra as ilusóes otimistas do humanismo. O termo genérico de "mal" reveste muitas formas de fontes de desordem: vingança, ambição, orgulho, ira, ciúme, desobediência, rebelião. A tragédia traduz dramaticamente estes males, convertendo-os em vivências das personagens, enquanto agentes ou pacientes.

Naturalmente, a aproximação entre MTC e o género trágico embate na diferença estrutural dos géneros literários praticados. Na galeria vastíssima de personagens que compóem o romance de Nemésio, na densidade formal da narrativa, na sucessão vertiginosa e simultânea de enredos paralelos que ironicamente se interligam, ou seja, na estrutura profunda de MTC, estamos em crer que Vitorino Nemésio enredou uma ossatura formalmente trágica $^{14}$.

Reler o romance segundo as caraterísticas do género trágico, tal como Aristóteles o expôs na sua Poética pode, por um lado, enriquecer a hermenêutica da obra e por outro constituir um modo alternativo de vislumbrar a apropriação do "Clássico" por um autor que explicitamente parece cético e crítico quanto à sua evocaçáo enquanto exercício cristalizado de identificaçâo face a uma matriz cultural.

A ação de MTC concentra-se num tempo e num espaço limitados para o padrão de um romance: menos de um ano, entre um Novembro de 1918, (cap. I) na cidade da Horta, recebido com os ventos ciclónicos do Outono, e o fim de agosto de 1919 (Epílogo), com o navio S. Miguel a fazer escala na ilha Terceira, e a prosseguir na sua viagem em direção ao Continente, num Exodo que retira do palco os sobreviventes da tragédia, que, tendo remoído

14 Aristóteles, Poética 1447a-1456a. Todas as citações da Poética são as de Valente 2004. 
gerações de famílias antagonizadas, teve o seu clímax nessa estreita faixa de tempo.

A protagonista - Margarida Clark Dulmo, apresenta um desenho eminentemente trágico, tal como Roberto e, em menor grau, João Garcia. É uma jovem de vinte e um anos, vemo-la nesse novembro ventoso em amores proibidos com João Garcia. Sabemos pelo Epílogo que ela teria casado em meados de Maio de 1919, pelo que temos, de facto, um horizonte muito concentrado para a ação dramática. Nesse Prólogo, nada deixa vaticinar que os amores espontâneos entre o jovem casal, espécie de Romeu e Julieta em versão açoriana, terão bom porto ${ }^{15}$.

O romance termina com Margarida desposada, num final formalmente aberto. Apesar da variedade temática da obra e das características estéticas e formais do género narrativo que apontam para a multiplicidade de açóes, o núcleo temático de MTC, embora tal não seja desvelado explicitamente ao leitor, é o casamento de Margarida ${ }^{16}$ : desde a promessa tímida de João Garcia, membro da família rival, nas vésperas da sua partida para Lisboa; passando pela aproximaçáo ao seu jovem tio Roberto, negada pela morte deste; até ao desenlace do casamento com André Barreto, filho dos Baróes da Urzelina, do Faial, que, como um deus ex machina, afasta do palco, não a Margarida do início do romance, mas a sombra cega dela mesma, o que restou após a catástrofe. Os acontecimentos modificaram profundamente as personagens sobreviventes, e, na verdade, o romance é "uma ação completa que forma um todo e tem uma certa extensão"17, a partir da qual há uma mudança de estado "de acordo com o princípio da verosimilhança e da necessidade, a sequência dos acontecimentos, mudando da felicidade para a infelicidade e vice-versa."

$\mathrm{Na}$ leitura das primeiras páginas, percebe-se que a vida amorosa da heroína trágica não é assunto exclusivo de coraçáo, antes está presa a um contexto familiar que a condiciona. Do seu casamento depende a salvação económica e a honra da casta aristocrática a que pertence. Mas nada é fácil. Há um lastro de ódio e de ressentimento sedimentado em vários estratos de

15 Poética 1452 b (definição de prólogo).

16 Poética 1450": "os acontecimentos e o enredo são o objetivo da tragédia e o objetivo é o mais importante de tudo (...) náo poderia haver tragédia sem ação...” (...) sobre a importância do enredo e da estruturação das ações: “....aqueles em que a tragédia exerce maior atração são as partes do enredo...”

17 Poética 1450b, 1451a, 1455b: “toda a tragédia tem um nó e um desenlace. Os factos exteriores à ação e alguns dos que constituem essa ação formam, muitas vezes, o nó, e o resto é o desenlace". 
ofensas, entre a família a que pertence, os Clark Dulmo, e a família burguesa dos Garcias, moradores na cidade da Horta, a que Joáo, o seu inocente amor nestes primeiros capítulos, pertence. $\mathrm{O}$ seu sangue não se misturará com o de uma família burguesa, de antigos empregados, próspera economicamente, mas odiada.

Em todo o romance, emerge a fragilidade conceptual dos patriarcas, herdeiros simbólicos de um património material e de prestígio, a cuja irrisão assistimos. São duas casas em desordem, desgovernadas pela cedência ao imobilismo e à moleza - o caso de Diogo Dulmo; ou por um espírito de vingança e rancor - o caso de Januário Garcia ${ }^{18}$. Estas duas heranças geracionais triturarão, não por linhas direitas, mas por agentes externos (a peste, o fogo) os heróis trágicos, as jovens geraçôes e a esperança de um desenlace feliz ${ }^{19}$.

Este ódio nasceu de uma ofensa ancestral, cujas manifestações do ressentimento acumulado nas personagens se escancaram brutalmente diante do leitor sem que se dê a saber facilmente o ponto de partida do mal, como se, de algum modo, este tivesse sido já substituído pela lembrança, ou pela cristalização do ódio, no correr do tempo. São as personagens secundárias, ou contextos paralelos ao da grande linha narrativa, que vão desvelando a verdade. Januário Garcia, pai de João Garcia, tinha ainda jovem trabalhado como administrador dos negócios dos aristocratas Clark. Pela lealdade e bons serviços nos negócios que julgava prestar, alimentara uma secreta afeição pela entâo criança Catarina Clark, filha do patrão, e que viria a ser a mãe de Margarida Clark Dulmo. Fora despedido com escândalo e envergonhado diante da restrita comunidade burguesa da Horta, graças a uma trama montada por um então jovem Diogo Dulmo, também de família aristocrata e de sangue antigo, como os Clarks. A mão de D. Catarina Clark e o acesso às grossas fortunas dos Clarks, acumuladas pelos ciclos económicos sucessivos: da laranja, do óleo de cetáceo proporcionado pela caça da baleia, dos pastos que alimentavam a criação de gado.

$\mathrm{O}$ ódio enquistado entre as duas castas não é, contudo, a única condicionante na ação de Margarida. Para a aristocracia tradicional, a que a família Clark Dulmo pertence, e para o "dinheiro velho", os tempos esta-

18 Poética 1453a: “...agora, as mais belas tragédias são compostas sobre um reduzido número de famílias”.

19 Poética 1453a: “...é forçoso que um enredo, (...) que a mudança se verifique, não da infelicidade para a ventura, mas, pelo contrário, da prosperidade para a desgraça, e não por um efeito de perversidade, mas de um erro grave..." 
vam a mudar ${ }^{20}$. À decadência de um modo de vida associa-se a dissolução moral: Diogo Dulmo desbaratara, com um comportamento perdulário, toda a fortuna que lhe fora parar às mãos. As propriedades da família iam servindo para amortizar as dívidas contraídas junto de fiadores, e é Januário Garcia, representante do "dinheiro novo", alguém que subira a pulso, com jeito para os negócios, movido pelo rancor e pelo desejo de vingança da humilhação passada, quem vai apertando o garrote aos velhos donos das ilhas, tomando posse das propriedades.

No casamento de Margarida, sendo ela o valor que resta à família Clark Dulmo, repousa a salvação do estatuto da família. Margarida não é ingénua nesta trama e sacrifica o coração à consciência de casta e aos imperativos familiares $^{21}$. João Garcia é filho do arqui-inimigo da sua família, jovem dado a versos e bacharel de direito por Coimbra, bem encaminhado numa vida que o destinaria a alto funcionário nas Ilhas, ou a oficial da marinha. As famílias opóem-se violentamente ao relacionamento entre os dois, embora Januário Garcia, vilmente, conceba um relacionamento que não tem lugar no temperamento sensível do seu filho, nem na altivez de Margarida ${ }^{22}$.

20 MTC regista também partes consequentes da história económica e social do Arquipélago, a viver de ciclos: o ciclo da laranja e das ervas tintureiras para o norte da Europa, que enriquecera os senhores da ilha, começa a ver o seu fim nestas primeiras décadas do séc. $\mathrm{XX}$. A caça à baleia, dominante no séc. XIX e primeiras décadas do séc. XX, vai perdendo relevo com a invenção de compostos de petróleo, que substituem o uso industrial do seu óleo (cf. MTC, XXIII, 273 os efeitos na economia local da decadência da caça à baleia). MTC apresenta esta fase de decadência dos ciclos tradicionais, e a ascensão do ciclo da criação de gado, nas mãos de novos proprietários de ascendência burguesa, "dinheiro novo", os que souberam aproveitar a decadência dos antigos senhores. A paisagem das ilhas torna-se dominada pelas pastagens verdes, cujo sucesso será associado à emigração que assolará as ilhas ao longo do séc. XX.

21 Cap. IX, 99: “...creia que não me queixo de nada, nem mesmo de nos termos falado sem pensarmos no que isso nos podia trazer de desagradável, pois não podemos esperar nada de agradável entre rancores lamentáveis".

22 Cap. XX, 203 "Margarida Dulmo chegara a ser para Januário uma pequena esperança de desforra; mas quê?! Para isso era preciso que João fosse outro homem, que se soubesse aproveitar do escuro dos cedros da quinta, fazer andar o carro à frente dos bois inclusivamente fugindo com ela para o Pico, fazendo rebentar uma escandaleira na Horta [...] a menina fina, a filhinha de seu papá, a elegante da rua do Mar, aparecendo de um dia para o outro de casaco de muita roda, barriga à boca, e ali os vomitozinhos da ordem no balde da madrugada (...) no dia seguinte, o ajuste de contas. Januário fechado com Diogo Dulmo no esconso de uma casa retirada, e as pedras do jogo para ali! Todas as farroncas por terra: "Meu caro senhor: se o meu rapaz se adiantou, é porque o trinco da porta não era de segurança. Quem quer filhas honradas, sopeia-as. "E agora?” Agora só há um remédio: casá-los. Eu livro o senhor das principais enrascadas (credores é cá comigo) e o meu amigo 
Margarida e João afastam-se um do outro, subjugados por uma trama familiar que lhes é superior.

O contexto espacial, o palco dos acontecimentos do romance, pode também merecer uma aproximação aos elementos da tragédia antiga: as ilhas açorianas, tal como surgem no romance, são espaços fechados em si mesmo, lugar em que todos os intervenientes se conhecem, e estão a par das histórias familiares. Os habitantes da Horta, pela voz de personagens secundárias, testemunharam os episódios de ofensas e escândalos entre as duas famílias, sobre eles refletem, avisam, sem alterarem o galope da ação trágica. Estas personagens secundárias no romance, Mateus Dulmo; o farmacêutico Alexandrino; Nina, o camarada de serviço militar de João Garcia; a avó de João Garcia, Maria Florinda; Ângelo Garcia, irmão de Januário Garcia; Manuel Bana; os baleeiros do Pico, alternam entre si a função ora de corifeu, ora de coro, pois assistiram aos eventos, narram-nos em analepses, ou a eles aludem em sentenças crípticas que os protagonistas devem interpretar...é todo um universo social que emerge de uma pólis, em que o destino individual de alguns, nomeadamente o da elite, abala a comunidade.

Tal como na tragédia de Sófocles, Rei Édipo, temos como pano de fundo de todo o romance uma epidemia de peste, que se tornará condicionante fundamental dos acontecimentos. É uma peste que cerca as personagens, aproximando-se insidiosamente. Começara entre os pobres, em S. Jorge ${ }^{23}$.

Nesse serão ainda, antes da falsa certeza de Ângelo Garcia de que a peste era para os pobres, do passado, a terrível doença trouxe para o presente a evocação da mãe de Joáo Garcia, condenada à morte em vida e segregada pela família: D. Emília Faria, esposa de Januário e mãe de João Garcia jazia, talvez com peste, na R. D. Pedro V, da Horta, ali junto do lugar em que jantavam. "Já tenho dito muita vez que essa pessoa, para nós, é como se tivesse morrido!" afirmava um resoluto Januário. Sob uma capciosa acusação de adultério, Januário e Henriqueta haviam expulsado de casa a mãe de Joâo Garcia, era ele menino de nove anos e sua irmã Henriqueta, entâo criança de colo. Emília levava, desde então, uma vida de reclusa, a ponto de

\footnotetext{
dota a pequena com uma parte razoável dos bens que eu, que não sou rancoroso, lhe livro das garras da hipoteca...".

23 Cap. III, 53, ao jantar, Januário lê alto o Jornal: "Na vizinha ilha de S. Jorge têm-se dado ultimamente alguns casos de peste, principalmente na vila da Calheta. O Sr. Dr. Manuel Nunes, digno guarda-mor de Saúde, tomou todas as providências que o caso requeria, não havendo motivo para alarmes. Januário dobrou o Jornal. Esta maldita peste não larga as ilhas! (....). Os pobres morrem como tordos, e, para Ângelo Garcia, irmão de Januário: «- Gente Bruta, que dorme com o curral do porco debaixo do nariz».
} 
nunca mais ter sido vista pelos filhos, João e Carlota. Vítima inocente de uma intriga, morrerá só, tarde demais para recolher o remorso da principal implicada na teia das mentiras, a irmã de Januário, Henriqueta ${ }^{24}$.

Esta, num último assomo, vestira o ancestral capote faialense, que até a tia Secundina, anciã sem idade, classifica de máscara de entrudo (VII, 101: "Estamos no Entrudo! Quem é que recebe máscaras para a menina se pôr nesse preparo?”). Dirigiu-se, anónima e solene, ao lar de Emília, encarando um cadáver abandonado no seu caixão, só pelo receio de contágio, coberto de cal. As palavras da Tia Secundina, associadas à evocação do anacrónico uso do capelo, assinalam a extemporaneidade do arrependimento de Henriqueta, chegado tarde demais.

O filho, João Garcia, será acometido também pelo remorso. Embora toda a família pressentisse a injustiça da acusação (apoiada em cartas comprometedoras de um amante que, lidas à justa, inocentavam D. Emília), numa sociedade em que a aparência e o olhar dos outros se tornam fundamentais para o indivíduo (falaríamos aqui da presença de uma cultura de vergonha ${ }^{25}$ ) não se levantaria a mancha de Emília. Em Lisboa, o militar Joáo Garcia recebia, no mesmo dia, duas cartas, a de Margarida Clark, a romper o namoro. Entrou um camarada de regimento, o Nina, que assiste à abertura da carta do tio Ângelo, a informá-lo da morte da mãe. O tom de Ângelo Garcia também é de contriçãa ${ }^{26}$, assinalando que, com a morte, se dissolvem todas as culpas.

24 Cap. V, 76, "a notícia da doença de Emília não deixara Henriqueta sossegar". Inquieta, refaz a intriga que protagonizara no passado e que condenara Emília à morte social. Durante a sua reflexáo, entrega-se a ferozes limpezas domésticas. Todos estão a par dos eventos trágicos do passado e esperam um ato de misericórdia e reconciliação para com a solitária Emília. O farmacêutico Alexandrino adverte Henriqueta (81) “...A D. Emília, muito mal (...) o tempo faz esquecer muita coisa, e, pelo menos, há obras de misericórdia que mandam perdoar aos que erram (...) Coisas da vida... perdoar aos que erram! Feio mundo!".

25 Dodds 1951: cap. I, II.

26 Cap. VII, 99. “...ninguém escolhe pais para nascer e também não devemos querer mal a quem já lá está à nossa espera e teve a cruz bem pesada (...) tudo o que se passou em casa n'outros tempos náo foi por culpa nossa nem talvez da minha pobre cunhada, são sinas...”. João conserva na memória a violência da expulsão de Emília da casa de família, como empestada em vida, a tia Henriqueta comandando a execução, e a cumplicidade silenciosa do pai que, embora pouco seguro da traição, não toleraria a suspeita e a mancha pública no juízo dos outros; (cap. VII, 102): "Henriqueta que abria a porta, amacacadinha e lívida, com um maço de cartas amarrotadas na mão «-para que a menina não tenha a porca confiança de negar!». Justiceira, atira ainda à pobre mulher: "E diga ao capitão Mota que vai assim toda fresquinha porque enjeitou o leite à filha!...cara sem ponta de vergonha!» João Garcia (lembrava-se disso como da morte!) viu a mãe desatar num choro explosivo 
João Garcia não foi inocente, neste processo: cooperara, com o seu silêncio, no ostracismo a que mãe fora votada, a ponto de não se lembrar como ela era, vivendo a dois passos de si. Sua avó Florinda alertara-o, quando jovem, para a falsidade das acusaçóes contra Emília, mas isso não o levara a agir: (cap. VII, 102) “-o menino respeite sempre o nome de sua mãe, que é tão sozinha no mundo". Ouvindo as confidências emocionadas de João, Nina atira-lhe (100) "Isso é que deve ficar como exemplo na tua vida. Por assim dizer, tens de vingar a tua mãe". João, abalado, diz que nem sabe bem o que significa "minha mãe" posto que não a conheceu... a sua morte reabilitou-a aos seus olhos e é, novamente, Nina que o alerta para o orgulho, para a hybris que comete "atreves-te a condená-la? Reabilitar? Reabilitar o quê?" ${ }^{27}$.

A peste não mais largará a cortina dos acontecimentos no romance. Neste episódio, ninguém, na família Garcia, fora capaz de compreender a falta trágica, o erro primordial, transportando-se este para as geraçóes seguintes, marcando-lhes o destino com o seu rancor. Henriqueta e João puderam escolher e, diante dos acontecimentos extremos, dissolver o erro, mas permaneceram dentro da ordem trágica. O passado semeou, mas é num presente disfórico, condicionado pelas consequências de decisóes erradas, que se colhem os frutos das escolhas e que se desencadeia a catástrofe ${ }^{28}$.

Episódios paralelos, de cegueira trágica face à catástrofe anunciada pela peste que se avizinha, ocorreu com a família Clark Dulmo, que, organizando um passeio à caldeira no centro da Ilha, atravessam a correr, em carros, com medo do contágio, uma paisagem desolada de caminhos de casas queimadas, para travar a disseminação da doença ${ }^{29}$. Enquanto os jovens empreendem o seu irrefletido e aziago passeio, os anciáos do clá discutem, em casa, os maus negócios da poderosa família. Ocorre então um momento catártico de visita a um passado doloroso. $\mathrm{Na}$ casa da família Clark, dá-se

e esmagado, torcendo as mãos para o Cristo amarelo e fumado dos Garcias «Meu Deus, Meu Deus! Eu caia redonda no chão se tive uma pinga de leite para a minha rica menina!».

27 Poética 1453b: "Na tragédia, o sofrimento ocorre entre pessoas de família..." O sofrimento causado pode ser causado com conhecimento ou sem conhecimento das personagens".

28 Williams 1966: 56, "The irreparable Action".

29 Cap. XI, 129. Tarde de Abril, excursão dos jovens da família à caldeira, organizada por Roberto, contra a vontade de Margarida e de Charles, "o Pico de cabeço roxo, cortado de uma nuvem cinzenta. Os carros atravessavam, com medo do contágio, casais atacados pela peste, casais queimados por ordem do delegado de saúde depois de outro foco pneumónico. Mas Roberto insistia que não havia contágio senão ao pé dos doentes ou tocando-se nas roupas infetadas..." 
o concílio dos patriarcas Charles Clark e Mateus Dulmo, respetivamente avô materno e tio-avô paterno de Margarida. Diante do desastre financeiro causado por anos de má gestão e desmandos de Diogo Dulmo, é uma casta, e um modo de vida, que contemplam a sua ruína eminente. Charles Clark lamenta ter sacrificado o seu único filho natural, Roberto, educado à distância em Londres, com a descrição recomendada para os casos de bastardia, aos desvarios da família legítima (Margarida e o indigno genro). Roberto, criado longe da mãe, do pai, e das ilhas, dispóe-se a sacrificar o seu quinhão da herança para salvar da bancarrota o bom nome e o estatuto da família que enjeitara (cap. XI, 131).

Mateus Dulmo desculpava como podia o sobrinho "de má cabeça", mas alerta "há a honra da família em jogo". Charles evoca da memória a falha primordial, fonte de todas as quedas posteriores ${ }^{30}$. Mateus é, de facto, um homem honrado, mas foi cúmplice, com o seu silêncio, da trama que beneficiou o seu sobrinho contra quem germinaria o azedume vingativo de Januário e dos Garcias.

D. Catarina Clark, mãe de Margarida, num transe de Cassandra que todos optam por ignorar, revive o passado traumático que perseguia a família como uma maldição, e trá-lo, como uma ameaça, para o presente indesejado da união dos sangues das duas família, Margarida e João ${ }^{31}$.

30 Cap. XI, 132: "E quem me obrigou, por telegrama, a despedir Januário, e tinha metido no escritório o patife do José Lemos, vosso parente, quando voltei?” Responde o anciáo Mateus: “- Tu carregas demais nas culpas do sangue, Carlos...Que diabo! Somos amigos de infância; eu era como um irmão da tua mulher... Nunca ofendi nem prejudiquei vocês. Sou um homem honrado!”.

31 Cap. XI, 133 “...Tudo isso é obra do Senhor Januário Garcia! Traz isto preparado de longe, na sombra! O pretendente à mão da filha do seu patrão é quase sogro da neta!... que expulsou a mulher de casa para fazer a vontade à irmá, à Garcia” ” (...) ...o baleia! Lembro-me como se fosse hoje! Eu era uma garota de tranças caídas. Aquela ternura, aqueles cuidados! Se chovia, encostava-me muito a si. Eu era uma inocente, nem reparava. Mas depois vinha do colégio a férias, mais pensada... Não! Aquilo não era natural. Fazia-se muito zeloso. Que a casa era muito rica....administrada por ele, era só darem-lhe dois anos, quando houvesse baleeiras a motor. O bola de unto! (...) Deixe-me o pai desabafar! Mas desde que o Diogo me pediu, nunca mais olhou direito para nós. Depois, na ausência do pai, descobriu-se tudo: os lucros que não escriturava; as dívidas fantásticas, sem documentos (...) mão baixa em tudo! Aquelas mãos amarelas, de sapo... aquelas abas: de coruja”. Os dois anciãos tentam calá-la: "-Basta, filha”. Diz Charles. E Mateus, gravemente: “- a D. Catarina esquece-se de quem é...” Ao que ela responde: -"é por me lembrar de quem somos, tio, e a pensar que estive arriscada a ter de chamar genro ao sobrinho da Garcia, ao menino prodígio!...e vamos que o perigo não passou..." 
Charles William Clark menciona a degradação do sangue trazida com o tempo ${ }^{32}$ : É de Mateus, em reflexão interior, que escutamos o contraponto para esta incapacidade de auto-análise de Charles. Ele náo era um santo, nem nos negócios, nem, sobretudo, na vida pessoal. Mateus, assumindo-se no papel de coro, desvela a reclusão a que condenou D. Margarida Terra, sua bela esposa, "a pérola do Faial", isolada de todos na casa do Granel, exibida em festas e remetida para a cristaleira.

A peste atingiu Manuel Bana, o leal e bruto criado de campo e de casa a que ficara reduzido o séquito de serviçais da outrora abastada família. Manuel é sombra protetora de Margarida (cap. XXII). Passada a folia das festas do Espírito Santo no Faial, Roberto, Margarida e Manuel Bana viajaram até ao Pico, com o fim de revitalizar a caça baleeira, pela entrada do jovem André Barreto, filho do Barão da Urzelina, de S. Jorge, na empresa da família. Bastou para que Margarida, a ama, Maria das Angústias, Roberto, ficassem retidos, em isolamento, a acompanharem o doente Manuel Bana. Forçados ao isolamento na Casa da Pedra da Burra, nas Vinhas, propriedade dos Dulmos, é desse lugar em que a morte brinca que discutem o destino dos negócios baleeiros dos Clark Dulmo, desejosos de quebrar o garrote de Januário; é desse lugar que Margarida amadurece a ambição de ir com o tio para Inglaterra, e aí se libertar das teias que lhe cerceiam a liberdade.

É daí também que contemplam o fogo que se ergue no horizonte próximo, na cidade da Horta à distância da travessia do Canal. Fogo e peste são acontecimentos simultâneos, irónicos avisos que a sorte vai lançando, ignorados pelas personagens trágicas. $\mathrm{O}$ fogo consome a casa de Januário. $\mathrm{O}$ incêndio e o rescaldo do desastre decorrem precisamente quando Januário fecha o cerco da humilhação da família Clark Dulmo, forçando o arresto dos barcos baleeiros do Pico ${ }^{33}$. A casa perdida para sempre, a tia Secundina, surda e acamada sem idade, memória da família, lúcida e livre de qualquer

32 Cap. XI, 133-4 "Perdoa, Mateus...mas Dulmos...salva-se o teu pai e salvas-te tu! Mateus expedia a própria vergonha em visôes e nexos rápidos. $\mathrm{O}$ irmão fora jogador e femeeiro. O sobrinho era um bêbado (...) mas o seu querido Charles William Clark não era um santo. Frio, teimoso. Aquela suficiência física de tudo a horas (...) Romanesco com o pai, sem grandes cabeçadas, navegando bem nos negócios desde que o leme andasse noutras mãos”.

33 Cap. XXIV, 240 “....A questão está ganha. A última palavra é nossa. Aí está, na probabilidadezinha certa é que eu jogo a cartada do crédito judicial”. Cap. XXIV, 239: “Todos os meios são bons quando se trata de um fim elevado como este: esmagar esse tratante do Dulmo! O malandro pensava que era só meter a filha à cara do Barreto e trazê-la à perna do tio, que a gente até nem sabe qual dos dois é o editor daquela pouca-vergonha?! Sócios na menina e na baleia, era de mais!". 
convenção social no modo como falava, desfez-se em cinza ${ }^{34}$. No cofre de ferro em que só ele mexia, estava a amorosa fotografia, envolvida de flores, da jovem Catarina Clark, tirada às escondidas quando a transportava na caleche do patrão... apagados estavam pois os vestígios de uma paixão impossível e doentia, que Catarina pressentira e revelara em transe.

É um torturado João Garcia, perdida a casa, a mãe, Margarida, perdidas todas as referências, que lamenta o desenlace trágico desta cadeia de males. Do ponto de vista da economia romanesca, João Garcia é, a partir deste episódio, uma personagem acabada, tolhida pela incapacidade de contrariar as consequências da herança de ódio que seu pai lhe deixara. Este lamento tem pois o sentido de um Êxodo para a tragédia da família Garcia ${ }^{35}$.

Após o incêndio da ilha do Pico, Margarida deixou cair todo o artificialismo da pose recomendada para a sua condiçáo aristocrata: deixa-se arrastar por uma itinerância incomum para uma rapariga da sua condição, numa viagem iniciática, da qual resultam perdas, mas também o conhecimento dos outros e de si: depois de cuidar do seu cuidador Manuel Bana, uma peripé$\mathrm{cia}^{36}$ transforma definitivamente o destino de Roberto e Margarida. Num verdadeiro clímax da ação, dois cachalotes são avistados no Canal, despertando a vocação baleeira das gentes do Pico, saturadas da inação motivada pela ruína financeira dos patróes. Contra a ordem do Juiz, num frenesim predador, fazem-se ao mar ${ }^{37}$. Atravessa o Canal com os baleeiros do Pico, numa perseguição à baleia que servirá de pretexto para salvar a frota da família Clark Dulmo do arresto, deixando o tio à deriva, na lancha, parado no

34 Cap. III, 57 “A surda era uma tia-avó dos Garcias, irmã do "escrivão-velho”. Dizia-se que tinha cem anos; era rija e medonha (...) há mais de dez anos que Secundina se não mexia dali...."

35 Cap. XXIV, 244 "A mim, estragou-me a vida! Contrariou sempre a minha vocação. Fez tudo para me amarrar àquele escritório medonho. Tudo segredos...manobras! (...) Eu perdoo a meu pai o mal que nos fez a nós, difamando a pobrezinha: a ela, a mim, à minha irmã. A Carlota ficou para ali uma triste, sem mocidade, agarradinha às saias da tia Henriqueta (...) eu engulo a vergonha de ver os meus amigos fazerem sinais uns aos outros quando se fala de maus passos. Morreu sem eu a ver, sem poder beijar minha irmã ...desprezada como um por cão! (...) - mas perseguir aquela família com tanto acinte! Tirar-lhe o último bocado...embrulhar-me no mesmo rancor que lhe têm a ele e fazer da nossa vida esta coisa feia, horrível, naquele covil que ardeu ontem sobre as indecências do tio Ângelo!...(...) - É o pai que ma rouba! E eu de quem gosto é dela!"

36 Poética 1452a: "Peripécia é, como ficou dito, a mudança dos acontecimentos para o seu reverso (...) de acordo com o princípio da verosimilhança e da necessidade".

37 O carácter e o destino dos aristocratas das ilhas afetam a comunidade, trazendo desemprego e penúria. Por isso, a perseguição dos cachalotes é um pretexto para esconder em S. Jorge os barcos ameaçados de penhora. É o pão dos baleeiros que está em jogo (Cap. XXIX, 281). 
meio do Canal. Seria esta a última vez que vê Roberto ${ }^{38}$. Arribados a S. Jorge, acompanhada por "homens agigantados, peludos, e apesar de tudo dóceis como meninos, ou pescadores do lago de Tiberíade", Margarida pernoita com eles numa grota. A cena é percebida pelos envolvidos como absurda e irreal ${ }^{39}$.

A peste vitima, por fim, Roberto. Isolada em S. Jorge pelo mar hostil e pela ausência de navios durante quase uma semana, Margarida recebe a hospitalidade dos Barôes da Urzelina, pais de André Barreto. Recebido um telegrama que lhe anunciara ter um tio muito doente, desconhece a identidade do tio que estaria muito doente. Por fim, tarde demais, sabe da morte de Roberto $^{40}$ : a narrativa, em analepse, surgiu pela boca de Manuel Bana, testemunha e mensageiro que, de dentro da sua rudeza sincera, reflete ${ }^{41}$.

Roberto preparava a partida para Inglaterra, ocultando-a de Margarida (Cap. XXXVI, 356). Quando fazia as malas, depara-se com um rato morto, empestado. Manuel ia para queimá-lo, mas Roberto teima em fazê-lo ele mesmo. $\mathrm{Na}$ incineração, saltam, invisíveis, as pulgas. $\mathrm{O}$ episódio náo é apenas fatídico, é profundamente irónico: na curta estada nas ilhas, Roberto entregara-se inconscientemente, por duas vezes, a este convívio próximo com a doença, endémica nas ilhas. Esta proximidade está de acordo com a indecisão de Roberto quanto ao seu destino, quanto ao envolvimento nos problemas da família paterna, na vontade ou náo de se investir do papel salvífico que os Dulmo Clark vêem nele. É quando amadurece a decisão

38 Cap. XXX, 288 "apoderou-se de Margarida uma espécie de íntimo terror, uma impressão de que fora abandonada ao mais apartado de si mesma -àquela zona de imagens, sensaçôes, pensamentos em que o sentimento da própria unidade não conseguia juntar os pedaços doloridos em que se sentia destroçada. E lembrando-se de que fora ela própria cúmplice daquela fuga absurda, se não quem a inventara do primeiro ao último pormenor com uma astúcia diabólica, concebeu um horror quase físico da sua pessoa: do jeito que tinha de levar criados, pescadores, velhas e velhos pitorescos; da sua resistência às provaçôes; da sua atração pelos perigos; de náo haver quilha ou quadrante que a fizesse enjoar".

39 Dizem os baleeiros companheiros da noite a Margarida (Cap. XXX, 296) "Adonde é que vossemecê oiviu dezer quós picarotos havero de varar im Sã Jorge co’ ua cozinheira destas, uma senhora do Faial"; "bota-se de conta que antrou polo telhado lá das vinhas uma feiticeira e deu a menina a uns lambusães" (sc. "lobisomens").

40 Poética 1452a: "Reconhecimento é, como o nome indica, a passagem da ignorância para o conhecimento, para a amizade ou para o ódio entre aqueles que estão destinados à felicidade ou à infelicidade" (...) desse reconhecimento e dessa peripécia depende o ser-se feliz ou infeliz...

41 Cap. XXVI, 357: “quem haverá de dizer qu’o alma do diabo que ua pulga, ua coisa qu' um home esmicha c'ao unha haverá de matar aquele senhor! Entes a peste me tivesse levado a mim! Mas comò oitro que diz, a sorte é cega...”. 
de partir definitivamente para a sua Inglaterra, que a peste, ou as ilhas, cobram o desafio que lhes fora lançado ${ }^{42}$. Roberto recorda-nos, naturalmente, a composição do herói trágico Édipo: rejeitado pela família, para ela é atraído em adulto, com a missão de salvar uma família e toda a comunidade.

Açor, o cão da família Clark, presta-se também a uma leitura enquanto elemento de um enredo trágico: Joáo Garcia, (Cap. I, 31) e Margarida conversam, cada um do seu lado do muro e do seu lado oposto do mundo. Joáo salta o muro para dentro da quinta propriedade dos Clark, e o cão atira-se a ele, obrigando-o a recuar para lá do muro. João Garcia não terá lugar na trama trágica que envolve a família. Teve de recuar para trás do muro. Pelo contrário, o esperado Roberto Clark, filho natural enjeitado de criança para, por fim, entrar na roda aristocrática pela porta grande, consegue aproximar-se de Açor, fazer-lhe festas, encantá-lo. Tal como Édipo, Roberto tem em Açor a sua Esfinge, que o seduz para dentro de uma realidade a que pertencera, de que fora expulso, e a que retorna, para ser consumido pela maldição familiar ${ }^{43}$. Subtil, até, a evocação do incesto, dado o interesse em que "ficasse tudo em família" pelo seu casamento com a sobrinha Margarida. Por fim, é ironicamente devorado por uma realidade de que, conscientemente, decidira, por fim, afastar-se.

Em MTC ocorre também a evocação dos mitos ancestrais, diríamos, os ciclos míticos das ilhas, em que se filiam as famílias nobres e os protagonis$\operatorname{tas}^{44}$. A estrutura compositiva de MTC está assim entretecida com os mitos fundadores da história real ou fantástica dos Açores, ligados à descoberta e colonização, com que as duas famílias, Dulmos e Clarks, se sentem implicados. Temos, por isso, um discurso pontilhado de analepses que fazem recuar profundamente as gerações: Diogo Dulmo, pai de Margarida, é o duodécimo neto de Fernáo Van Hulm, navegador flamengo ao serviço do infante D. Henrique "descobridor de uma suposta ilha ao norte da Terceira, neto do capitão-mor Diogo Dulmo, que hospedou na sua casa o Senhor D. Pedro IV” (Cap. II, 42). História e fantasia cruzam-se, pois não existe nenhuma décima ilha ao norte da Terceira. Mas ficara a memória de que, no séc. XV, a Fernáo Dulmo tinha faltado, por morte de D. Henrique, apoio para uma expedição que confirmaria esta nova descoberta, que seria a Ilha das Sete

42 Poética 1452a 57, definição de "peripécia”.

43 Cap. IX, 113 "Roberto, que fizera o milagre de amansar o Açor falando-lhe grave e de mão bem aberta...”.

44 Poética 1451b: "Na tragédia os poetas prendem-se a nomes reais e a razão disso é que o possível é fácil de acreditar...” 
Cidades. Igualmente maravilhosa é a origem da família Clark na Horta. O trisavô Ralph Clark, navegador e comerciante inglês, tomara-se de amores repentinos por uma freira, filha das melhores famílias do Faial, que raptaria do Convento da Glória, na Horta. Funda-se com sangue estrangeiro, nas ilhas, a linhagem Clark, comerciantes que, estabelecidos em Inglaterra, fazem das ilhas casa-mãe, casulo e cemitério de luxo para as mulheres que encerram em solares, emparedadas vivas, que não acompanham os homens nas suas aventuras por mar e por terras longínquas. De igual modo, o avô Charles Clark desposara D. Margarida Terra, avó de Margarida, da linhagem dos primeiros povoadores de ascendência portuguesa, os Terras.

Esta identificação com a história, os mitos ancestrais e com o religioso não é exclusiva dos abastados. Revivido pelos mais humildes, entranha-se nos comportamentos, justificando condicionamentos atávicos. Veja-se o exemplo do que diz o narrador sobre as festas do Espírito Santo ${ }^{45}$. As festas são vividas numa explosão de alegria quase pagã (sc. a referência aos Floralia), a pomba, símbolo animal do Espírito Santo, evoca o corvo marinho com que o lugar incerto desta Macaronésia era anotado na cartografia maiorquina e veneziana. Este paraíso reencontrado, reino de encontro harmonioso entre homens e Deus, é assim sentido por um paradoxal e comovido Manuel Bana, mordomo nesse ano, que declara solenemente "Imparador do seistimo domingo: Chico Bana!".

Num outro passo emerge o passado mítico das ilhas, com uma história real de extermínio. A natureza vulcânica das ilhas marcou o seu povoamento com um ciclo de aniquilaçóes e de renascimentos para novas eras. Margarida lê, na Casa dos Baróes da Urzelina, em que se acolhera após a arrojada travessia do Canal, na Miscelânea de Garcia de Resende "O Romance que se fez d'alguas mágoas e perdas que causou o tremor de Villa Franca do Campo, em 1522 ", versão poética do cataclismo que pôs fim à primeira capital e mais antiga cidade das ilhas. Soterrada, os sobreviventes cavaram dias a fio para

45 Cap. XVIII, 185: "As festas do Espírito Santo enchem a Primavera das ilhas de um movimento fantástico, como se homens e mulheres, imitando os campos, florissem. Da Páscoa ao Pentecostes e à Santíssima Trindade são sete ou oito semanas de ritos de uma espécie de florália cristã, adaptada a vida da lavoura, dos pastos carregados de humidade e de trevo no meio das escórias de lava (...) o Espírito Santo, aberto numa pomba de prata ao topo de uma coroa real, liga o Pai do Céu aos seus filhos das ilhas dos Açores como a própria ave que marcava nos postulados de Maiorca e de Veneza aquelas paragens mortas: Insula Columbi...Insula de Corvi Marini ...Primaria siue puellarum”. As Festas iniciam-se no Domingo após o Pentecostes, o sexto após a Páscoa. 
recuperar os mortos. Alguns, no meio-termo entre morte e vida "comiam biscoitos de bordo, passageiros da barca de Caronte. Agora, Lázaros vivos".

Trata-se de um motivo recorrente no romance, o da permanência simultânea dos dois estados, morte e vida, ou da morte em vida: Margarida Terra Emília Garcia, Ana Silveira, a mãe de Roberto, a própria tia Secundina "a dever anos à cova". A morte em vida de Margarida, por fim, que sacrifica o amor a João Garcia ao imperativo lançado por Mateus Dulmo "tudo o que fizeres pelos teus é como se o fizesses por ti” (cap. XIII, 154). A ironia trágica revela-se em toda a sua intensidade quando, diante da vida, ou libertação de um destino de "emparedada" ou de destinada ao sacrifício de um casamento de conveniência, que o tio Roberto lhe propóe com a partida para Inglaterra, Margarida escreve a Joâo Garcia, anunciando-se noiva (cap. XIV, 158). Anunciar um casamento sem noivo (neste ponto do romance, André Barreto ou Roberto Clark?) significa libertar-se do amor como motivação principal da sua ação, e, secretamente, colocar no tio a esperança de libertação. Neste caso, ela estaria a anunciar o noivado com Roberto, o esperançoso vivo, prestes a ver a vida ceifada pela peste. Neste sentido, Margarida assume acordes de Antígona sofocleana, a que entoa o seu himeneu a caminho da gruta em que seria emparedada, numa paradoxal evocação desta sobreposiçáo da vida e da morte. Do mesmo modo se aproxima da heroína trágica, ao acompanhar o funeral de Roberto, regressado à sua condição de filho rejeitado, como Polinices.

Além da substância mítica e religiosa que perpassa e condiciona a açáo dos vivos, o espaço dota-se de um significado trágico. Se a tragédia é o género literário da pólis, que questiona o indivíduo na sua interação com o político, com o ético e com o religioso, as ilhas açorianas são aqui tratadas, isoladamente, como um microcosmos, sistema fechado dentro de um universo único, coerente mas fragmentado, no qual a mesma substância humana se movimenta (todos se conhecem), percebendo, em cada passo, o afastamento face ao seu espaço de conforto, diríamos, a sua terra-mãe: as ilhas são o espelho da fragmentação, as dificuldades episódicas e os desencontros motivados pela incapacidade de as personagens principais se deslocarem condicionam os seus destinos; os Faialenses são estrangeiros no Pico, os Picarotos são estrangeiros em S. Jorge, e assim sucessivamente, neste espaço único em que uma ilha, enquanto geografia e enquanto espaço social, se define no confronto, no estar em face da outra.

A dimensão trágica das personagens Margarida, João e Roberto está também presente no facto de, para todos eles, a figura materna ser inexistente ou difusa. Todos são órfãos de mãe, real ou metaforicamente: Margarida recusara o seio materno e o de qualquer mulher, tivera em Manuel Bana a 
figura do seu centauro pedagogo. Roberto, filho de amores inconvenientes entre Charles Clark e uma senhora "fina", fora afastado das ilhas para retirar da vista de todos a prova do escândalo. Crescera desempoeirado por uma educação britânica, entregue com sucesso a uma carreira comercial em Londres. Regressou aos quarenta anos, para abraçar o pai nos seus últimos dias de vida, mas recebe a investidura de salvar, com sangue e dinheiro novos, família e negócios exangues. A ironia trágica fará dele uma vítima: no momento em que escolhe recusar o universo social das ilhas, preparando-se para regressar, subitamente, às ilhas de adoção que o receberam de criança, é contagiado pela peste. $\mathrm{Na}$ hora derradeira, assumiu a sua condição de filho indesejado, e requereu para si, não o jazigo dos Clarks, mas o chão comum do cemitério, onde jazia a mãe que não conhecera.

Margarida está "assinalada" na testa, por uma cicatriz de uma queda de um garrano, feita na infância. Margarida é uma personagem intrépida que, apesar da assunção solene do fardo familiar, tem algo de inumano: em criança, rejeitara todos os seios humanos, tendo sido criada com o leite de uma cabra amarela (Cap. II, 41). Margarida nunca chora, diz dela a mãe (cap. II, 46).

Portadora da "serpente do anel" (Cap. I, 34) que lhe deixara a avó, Margarida Terra recebeu-a já como serpente cega, pois perdera as esmeraldas dos olhos. Quando exibiu o anel a Joáo, e este o beijou, comovido, levantou-se, ominosamente, um ciclone, que obriga o casal a acelerar a despedida daquele encontro fortuito, afinal o último que teriam.

Margarida tem consciência do seu desígnio sacrificial. O primeiro destes atos expiatórios de culpas que náo eram suas, apresentado pelo pai, manchava-se pelo interdito do incesto. Casar com o tio Roberto, o filho natural enjeitado que prosperara em Inglaterra, traria a paz financeira à família. É o pai que a empurra para estes esponsais ${ }^{46}$. Depois de conhecer Roberto, Margarida sentiu-o próximo e estranho à realidade das ilhas. Por isso, viu nele a possibilidade de se evadir das ilhas para Inglaterra, para onde não carregasse o fardo familiar. Num monólogo lúcido, Margarida assume a amargura face ao que esperam dela, mas sobe ao altar sacrificial ${ }^{47}$. As suas oscilaçóes pelos três

46 Cap. IV, 76 "Escuta o pai: o tio Roberto vem aí (...) sim, porque numa hora cai a casa...entendes. Isto e traçava com a máo livre um arco vagabundo que abrangia a mesa, o aparador carregado de pratas, o quarto do velho lá adiante, os tetos, a quinta - é tudo um ar que se lhe dá. Cabeçadas do pai - Teu avô era quase um velho quando o filho nasceu; a mãe não te era nada. Se ele te agrada, deixa...casa! Que fica tudo em família!”

47 Confessa a Roberto (Cap. XIV, 156) “...Numa terra em que tudo são heranças e negócios, o que vale uma rapariga? Se eles já não têm a que se tornem, a gente não lhes pode servir? Sim, é dispor, pois então! Eu sou uma espécie de prédio que por acaso ficou livre. Muito mais 
potenciais pretendentes, João Garcia, Roberto Clark e André Barreto, têm pouco de romântico: desposará o homem que liberte a sua família do sufoco financeiro em que se encontra e o que a tirar do seu destino de emparedada num qualquer solar das ilhas. Por fim, isolada em S. Jorge, Margarida vive a angústia de não saber qual dos seus tios corria risco de vida, e luta com todas as forças para romper a imobilidade a que a condição insular a vota, por falta de um barco que a leve a um destino que, ironicamente, consegue ver diante de si. Regressa ao Faial, por fim, para prestar homenagens fúnebres a Roberto, a sua derradeira esperança de uma vida além do fado das ilhas.

No epílogo, sabemo-la casada com André Barreto, novo sócio dos negócios do pai. Nora dos baróes da Urzelina, Margarida casou dentro da sua estirpe. Esta submissão ao destino, amargamente aceite, é tragicamente assumida no seu gesto final, quando, da amurada do navio em direção ao continente, devolve ao anel de serpente a cegueira que o jovem marido, ingenuamente, julgara dever compor. Metáfora dela mesma, arranca-lhe com violência as esmeraldas dos olhos, porque (Cap. XXXVII, 388) "se sentia cega como a serpente do anel que nenhum ventre de peixe levaria a mesa humana e que àquela hora jazia, como a cucumária dos abismos, no mais secreto mar". Por fim, lança o anel aos abismos profundos do mar açoreano, de onde não voltará, fazendo companhia à sua versão viva das profundezas, a desprovida de olhos cucumaria abyssorum, habitante a milhares de braças.

Neste epílogo, Nemésio faz uso do que entendera ser a sua relação com o clássico: um diálogo vivificador e subtil com a história e os mitos: ao contrário do anel de Polícrates de Heródoto, que voltará às mãos do proprietário, o anel de Margarida nunca se recuperará, pois o mar dos Açores é um mar abissal, ao contrário do Mediterrâneo dos Gregos.

deve um filho «a seus progenitores» (não é assim que se diz?) (...) Já fiz a primeira comunhão; crismaram-me...vamos chegando à altura das flores de laranjeira. A vida é como a roda do ano em casa do lavrador: lavrar, semear, ceifar... Não ouve o que diz a mãe? Esta rapariga não é como as outras, não se sabe divertir! Qualquer dia morro e fica para aí desamparada!”. 


\section{Paula Barata Dias}

\section{Bibliografia}

Aristóteles (2004), Poética. Tradução de Valente, A. M. Lisboa: Fundação Calouste Gulbenkian.

Baptista, J. M. D. (2012), “A açorianidade segundo Vitorino Nemésio”, in Contributos para uma noção de açorianidade literária. Lisboa, Universidade Aberta: 17-19. https://repositorioaberto.uab.pt/.

Bloom, H. ('1973), The anxiety of influence: a theory of poetry. Oxford: Oxford University Press; trad. port. Tamen, M. ( $\left.{ }^{2} 1991\right)$, A Angústia da influência. Lisboa: Gradiva.

Cardoso, M. J. (2005), A Sedução de Prometeu. Nemésio e o Clássico (dissertação de mestrado).

(1988) Comemoraçôes do $10^{\circ}$ aniversário da morte de Vitorino Nemésio. Arquipélago. Linguas e Literaturas 10 .

Dodds, E. R. (1951), The Greeks and the Irrational. Berkeley: University of California Press.

Floisel, E., Ribeiro, M. F. (2007), Vitorino Nemésio e intelectuais portugueses no Brasil. Congresso Internacional de Estudos Nemesianos. Salvador: Direção Regional de Cultura do Governo dos Açores.

Lepecki, M. L. (1971), “Sobre Mau tempo no canal”, Colóquio Letras 4: 44-49.

Nemésio, V. (1916), Poesia. I. Lisboa: INCM.

Nemésio, V. (1932), "O Açoreano e os Açores”, conferência proferida na Associação Académica de Coimbra, 13 de Fevereiro de 1928; "Açorianidade”, Insula, Número Especial Comemorativo do V Centenário do Descobrimento dos Açores 7-8 (Julho-Agosto). Ponta Delgada.

Nemésio, V. (1938), "Um conceito de clássico. A propósito do I volume dos Anais de D. João III de Francisco Luiz de Sousa, ed. Rodrigues Lapa, col. Sá da Costa”, Revista de Portugal 5. 1: 99-101.

Nemésio, V. (1952), Nem toda a noite a vida. Lisboa: Ática.

Nemésio, V. (2008 reimpr.), Mau Tempo no Canal. Lisboa: Relógio d’Água.

Pires, A. M. et al. (eds.) (1998), Vitorino Nemésio, Vinte anos depois. O Colóquio Internacional. Lisboa / Ponta Delgada: Edições Cosmos.

Williams, R. (1966), Modern Tragedy, London: Encore Editions. 
Maria de Fátima Sousa e Silva é Professora Catedrática do Instituto de Estudos Clássicos da Universidade de Coimbra. Desenvolveu, como tese de doutoramento, um estudo sobre a Comédia Grega Antiga (Crítica do teatro na Comédia Grega Antiga), e, desde então, tem prosseguido com investigação nessa área. Publicou já traduções comentadas de nove comédias de Aristófanes, além de um volume com a tradução das peças e dos fragmentos mais significativos de Menandro.

Maria das Graças de Moraes Augusto é Professora Titular no Departamento de Filosofia do Instituto de Filosofia e de Ciências Sociais da Universidade Federal do Rio de Janeiro (UFRJ). A sua investigação sobre História da Filosofia Antiga abrange temas como Platão e a herança platónica, filosofia e conhecimento no pensamento antigo, filosofia e literatura na tradição antiga e recepção dos clássicos gregos no Brasil.

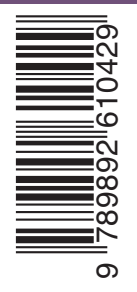


OBRA PUBLICADA

COM A COORDENAÇĀO

CIENTÍFICA
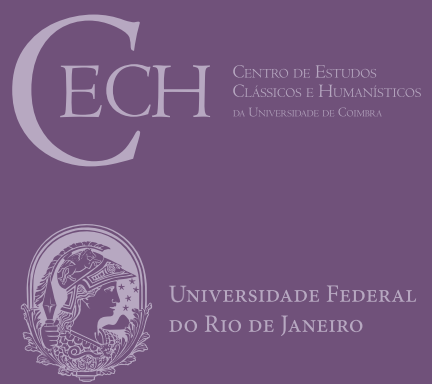

- U 